\title{
Microhabitat Utilization by the Megafaunal Assemblage at a Low Relief Outer Continental Shelf Site - Middle Atlantic Bight, USA
}

\author{
Peter J. Auster, Richard J. Malatesta, Susan C. LaRosa, Richard A. Cooper, and Lance L. Stewart \\ NOAA's National Undersea Research Center, The University of Connecticut at Avery Point \\ Groton, Connecticut 06340, USA
}

\begin{abstract}
Direct underwater observations, using a manned submersible (May 1987) and remote operated vehicle (July and November 1988), were made of the small-scale distribution and microhabitat relationships of the megafaunal assemblage at a $55 \mathrm{~m}$ low relief outer continental shelf site $\left(40^{\circ} 50^{\prime} \mathrm{N}, 70^{\circ} 55^{\prime} \mathrm{W}\right)$. Four microhabitat types were defined: flat sand with amphipod tubes, sand wave crests, shell (single valves and valve aggregates) and biogenic depressions. Microhabitat heterogeneity occurred on the scale of meters. Significant species-specific microhabitat relationships were found. Temperature mediated mesoscale shifts in megafaunal-microhabitat associations were found for several species.
\end{abstract}

\section{Introduction}

Much of our understanding of the distribution, activities and interactions of megafaunal species (e.g. finfish, squids, scallops), in temperate and boreal marine environments, comes from trawl sampling (Auster, 1988). Although trawls are not very efficient (Uzmann et al., 1978), this approach is valuable for discerning mesoscale patterns (approximately 1 to $1,000 \mathrm{~km}$ ). For example, interspecific associations and faunal zones off the northeastern United States have been defined using cluster analysis techniques on seasonal catch data from research bottom trawls (Colvocoresses and Musick, 1984; Overholtz and Tyler, 1985; Phoel, 1986). These studies found that significant megafaunal species associations tended to follow isotherms and isobaths. In particular, nearshore and midshelf species were more influenced by variations in temperature while deep shelf and slope species were more influenced by depth. Groups of species were seasonal and often split or combined with adjacent groups due to temporal changes in temperature patterns. No mesoscale correlation with sediment type was found.

Species can be separated into year-round, winter and summer residents, and occasional migrants (Tyler, 1971). Areas with wide temperature fluctuations, like the Middle Atlantic Bight (Parr, 1933), are dominated by temporary residents (Colvocoresses and Musick, 1984; Phoel, 1986). It is interesting to note that in boreal areas such as the Scotian Shelf, which have narrow temperature fluctuations and are dominated by yearround residents, the mesoscale distribution patterns of finfish are correlated with bottom type (Scott, 1982; but see Mahon and Smith, 1989).
Most of our understanding of small-scale interactions (e.g. competition for space or prey, predator-prey dynamics, species-habitat associations) affecting the dynamics of marine fish assemblages have come from studies on tropical coral reef systems (e.g. Hobson, 1974; Hobson and Chess, 1977; Sale, 1972, 1975, 1977, 1978, 1984; Smith, 1978; Smith and Tyler, 1972, 1973, 1975). Much less is known in temperate and boreal marine environments (e.g. Ebeling et al., 1980; Hobson and Chess, 1976, for kelp bed fishes; Gascon and Miller, 1981 for North Pacific rock reef fishes; and Cooper et al., 1987 for Georges Bank submarine canyon assembages, are exceptions), although such interactions are inferred from data collected using trawls (e.g. Hacunda, 1981; Langton and Bowman, 1980, 1981; Sedberry, 1983).

Herein we describe small-scale habitat variability, faunal-microhabitat relationships related to that variation, species-specific behavior patterns, and seasonal changes in megafaunal composition at a low topography site in the Middle Atlantic Bight.

\section{Materials and Methods}

The study site (Fig. 1) is an area known locally as "The Fingers" (approximately $40^{\circ} 50^{\prime} \mathrm{N}, 70^{\circ} 55^{\prime} \mathrm{W}$ ). The name comes from the finger-like pattern of the $55 \mathrm{~m} \mathrm{(30}$ $\mathrm{fm}$ ) isobath on nautical charts. The area is well known to fishermen for seasonal aggregations of pelagic sportfish (e.g. tunas, sharks) and groundfish.

Initial reconnaissance of the site was accomplished with the two person submersible DSRV Delta 


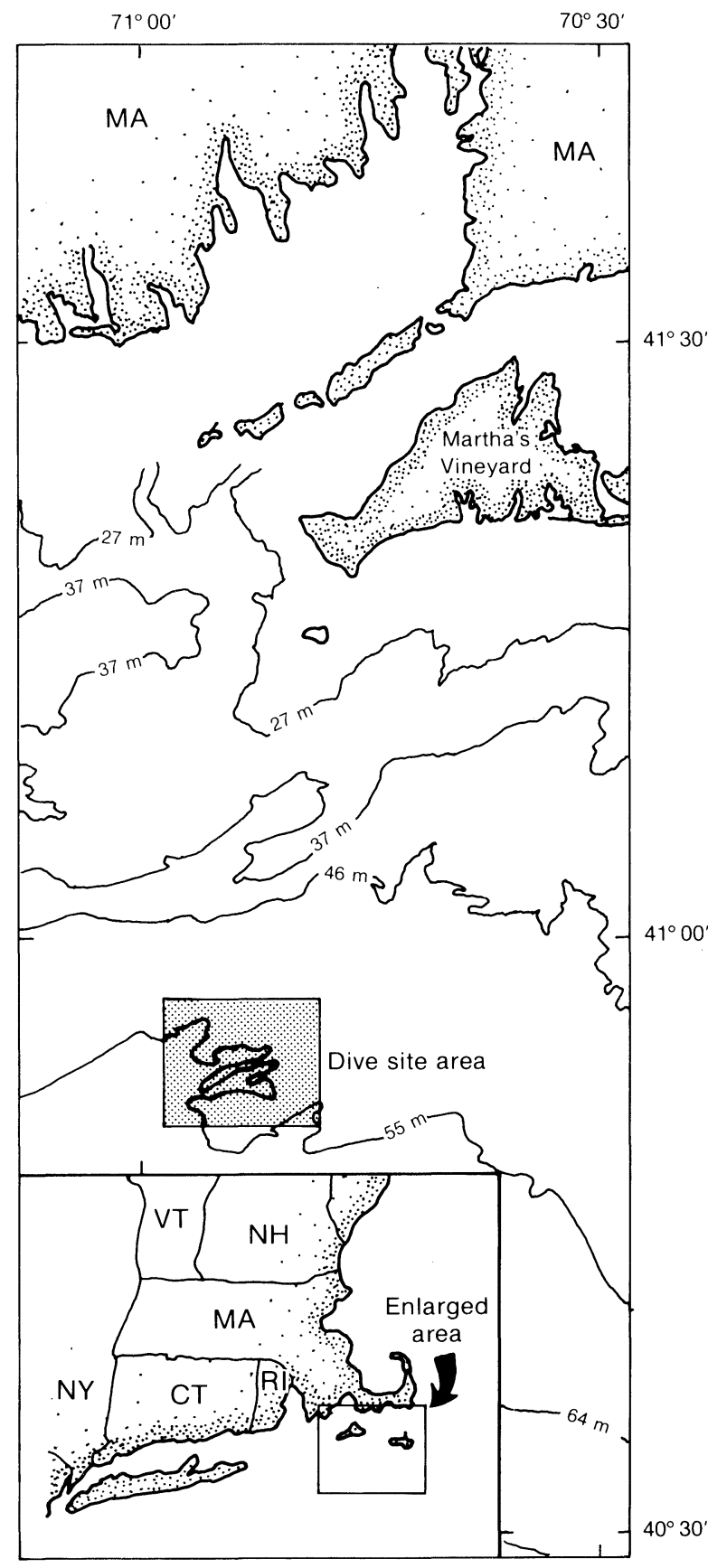

Fig. 1. Location of the study site.

(Delta Oceanographics, Torrance, California, USA) on 16 May 1987 (Dive 582). A representative video transect was run across the site with an uncalibrated camera at variable angles. Additional still photographs were taken and general observations recorded. From the video tape, still photographs and direct observations, microhabitat types were identified and faunalmicrohabitat relationships were recorded.

A remote operated vehicle (ROV) was used for visual observations on a cruise conducted from 11 to 15 July 1988. The support ship was at anchor for all ROV

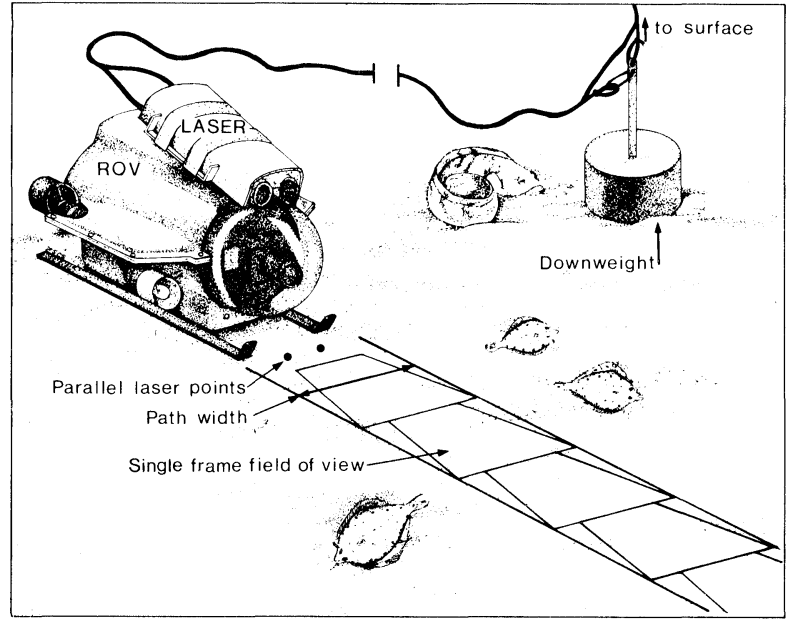

Fig. 2. A conceptual drawing of a ROV transect. Individual, nonoverlapping video frames can be treated as a series of adjacent quadrats. The paired lasers are used to estimate path width for strip transects and to measure sizes of objects in situ. A $50 \mathrm{~m}$ transect is measured by running $50 \mathrm{~m}$ of tether out from the downweight.

dives. The video camera in the ROV was calibrated for area of coverage at a specific tilt angle (Auster et al., 1989) and 1 to 3 quantitative $50 \mathrm{~m}$ transects were made at each of six stations depending upon sea state and current conditions. Transects were run both day $(n=9)$ and night $(n=7)$. A transect began at the ROV downweight and ended when the $50 \mathrm{~m}$ of tether was fully extended (i.e. the vehicle could no longer move forward; (Fig. 2). The area covered by each transect was $42.64 \mathrm{~m}^{2}$. Qualitative observations of animal behavior were made at each station after quantitative transects were completed. Additional observational dives were also conducted at areas around the general study site.

A video editing system with single frame advance facilitated viewing of individual video frames. Each transect was treated as a series of 42 non-overlapping adjacent quadrats $\left(1.015 \mathrm{~m}^{2}\right)$. For each quadrat, all megabenthic species (i.e. all visible fauna) were enumerated and coded for microhabitat type.

No significant diel differences were found for any species (Mann-Whitney U-tests, $P>0.05$ ) so all data were pooled. Furthermore, individual transects showed no statistical differences in abundance by species and were also pooled (U-test, $P>0.05$ ). To test for heterogeneous species distributions, a Chi-square test of homogeneity of distribution was computed for each species sorted by microhabitat type. Expected values were weighted for unequal distribution of microhabitat types from the survey data. A Pearson's product moment correlation coefficient was computed to discern positive or negative associations for each species with each microhabitat type.

In order to more fully characterize microhabitat categories, grab samples $(21 \times 24.5 \mathrm{~cm})$ were taken for 
each microhabitat type (except biogenic depressions), at ROV verified positions. Sediment grain size analysis was performed on each sample. Grain size was determined by measuring the longest dimension of 300 individual grains under a calibrated microscope and computing the mean. Voucher specimens of shrimp were collected with a towed epibenthic zooplankton sled with 1-mm mesh net.

To ascertain size class representation of several fish species, sizes of individuals were estimated from the video images. Individuals passing perpendicular to the axis of the camera lens were measured to the nearest centimeter by comparing them to the distance between beams from a pair of parallel lasers attached to the ROV (Auster et al., 1989).

Another cruise conducted on 15 November 1988 was limited by poor weather conditions. Sea state limited stable ROV transects of a known length and height off bottom to only four night transects at one station. Video data were treated like those from the 1987 dive. Qualitative observations of animal behavior were also made.

Seasonal patterns of species composition and microhabitat use were summarized qualitatively. Temperature patterns at the site were estimated using a geographically based interpolation program from 10 years of Northwest Atlantic temperature data (Mountain, MS 1989).

The species observed at this site were: red hake (Urophycis chuss); silver hake (Merluccius bilinearis); little skate (Raja erinacea); ocean pout (Macrozoarces americanus); longhorned sculpin (Myoxocephalus octodecimspinosus); scup (Stenotomus chrysops); butterfish (Peprilus triacanthus); flounder (Pleuronectiform spp.); monkfish (Lophius americanus); sea robin (Prionotus sp.); ocean quahog (Arctica islandica); ocean scallop (Placopecten magellanicus); longfinned squid (Loligo pealei); American lobster (Homarus americanus); Jonah crab (Cancer borealis); hermit crab (Pagurus longicarpus); shrimp (primarily Crangon septemspinosa and Dichelopandalus leptocerus); hydroid (Tubularia sp.); tube worm (Myxicola infundibulum); starfish (primarily Asterias vulgaris and Henricia sanguinolenta); and sponges (Suberites ficus). Common names will be used throughout the remainder of the text.

\section{Results}

\section{May 1987}

Four microhabitat types were defined from the initial DSRV Delta dive: flat sand with amphipod tubes, sand wave crest, shell (dense patches and individual valves of the ocean quahog), and biogenic depression (whether in flat sand or under and around shell). A very dense patch of ocean quahog valves was a conspicuous part of the local habitat and small patches and scattered individual valves were common throughout the area. Sand wave crests were spaced 1 to $3 \mathrm{~m}$ apart interspersed with flat sand and amphipod tubes. The flat sand substrate was contiguous in areas of no sand waves. Sand waves may have been the result of turbulence generated near bottom by winter storms. The crests were rounded and had sparsely attached epifauna and amphipod tubes indicating no recent movement.

Several significant generalizations could be made from the observations of species by microhabitat type (Table 1). First, the shell habitat had the most species per unit area. Interstices of overturned and overlapping valves served as shelter sites. Second, the majority of individuals of all species, except lobster, were visually estimated to be in juvenile size ranges. Finally, each species used the habitat in a specific way for shelter and foraging.

Lobsters occurred primarily in depressions excavated through the dense shell cover (Fig. 3A). This could be the result of foraging for live ocean quahogs which occurred under the surface valves or simply creating daytime shelter or both. Young-of-the-year ocean pout were an abundant component of shell associated megafauna. Individuals were found under and alongside hinged and single valves, which they apparently were using for shelter (Fig. 3B). Silver hake were often oriented into the current on the downcurrent side of sand wave crests. Four individuals were observed to prey on drifting demersal zooplankton (e.g. shrimp).

\section{July 1988}

Quantitative ROV transects showed that microhabitat type varied on the scale of meters (Fig. 4). Grain size analysis from grab samples showed sand wave crests had the coarsest grain size $\left(\bar{x}=0.544 \mathrm{~mm}, \mathrm{~s}^{2}=\right.$ $0.073)$, followed by flat sand with amphipod tubes $(\bar{x}=$ $\left.0.480 \mathrm{~mm}, \mathrm{~s}^{2}=0.061\right)$ and dense shell $\left(\bar{x}=0.293 \mathrm{~mm}, \mathrm{~s}^{2}=\right.$ $0.016)$. Pairwise comparisons (t-tests) showed all three

TABLE 1. Summary of distribution and abundance (numbers) of taxa by microhabitat type from DSRV Delta dive 582 video transect (May 1987)

\begin{tabular}{lcccc}
\hline \hline & \multicolumn{4}{c}{ Microhabitat type } \\
\cline { 2 - 5 } Taxa & $\begin{array}{c}\text { Flat sand } \\
\text { with amphipod } \\
\text { tubes }\end{array}$ & $\begin{array}{c}\text { Sand wave } \\
\text { crests }\end{array}$ & Shell & $\begin{array}{c}\text { Biogenic } \\
\text { depressions }\end{array}$ \\
\hline Ocean pout & 2 & 3 & 22 & 0 \\
Little skate & 7 & 1 & 3 & 1 \\
Red hake & 2 & 3 & 5 & 2 \\
Silver hake & 7 & 3 & 1 & 1 \\
Flounder & 5 & 2 & 1 & 0 \\
Lobster & 2 & 0 & 2 & 12 \\
Jonah crab & 1 & 0 & 7 & 2 \\
Hermit crab & 0 & 0 & 6 & 0 \\
Ocean scallop & 1 & 1 & 3 & 6 \\
Starfish & 92 & 32 & 2 & 0 \\
Tube worm & 22 & 0 & 47 & 0 \\
Hydroid & 120 & 11 & 92 & 0 \\
\hline
\end{tabular}



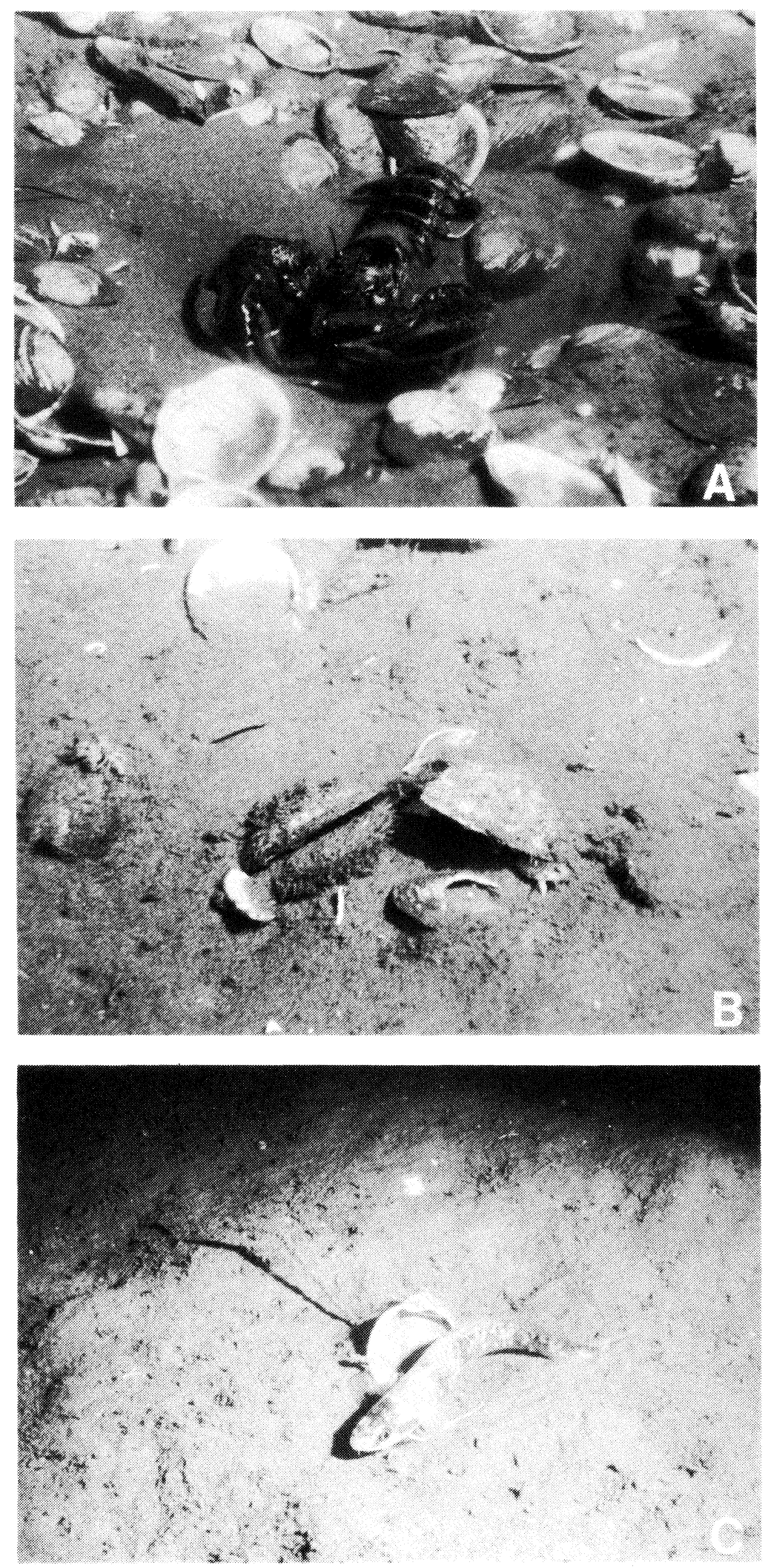

Fig. 3. (A) An adult lobster in a dish depression excavated into the shell covered bottom. (B) Young-of-the-year ocean pout using an overturned ocean quahog valve for shelter. (C) A red hake exhibiting a thigmotactic response to a partially exposed ocean quahog valve. 


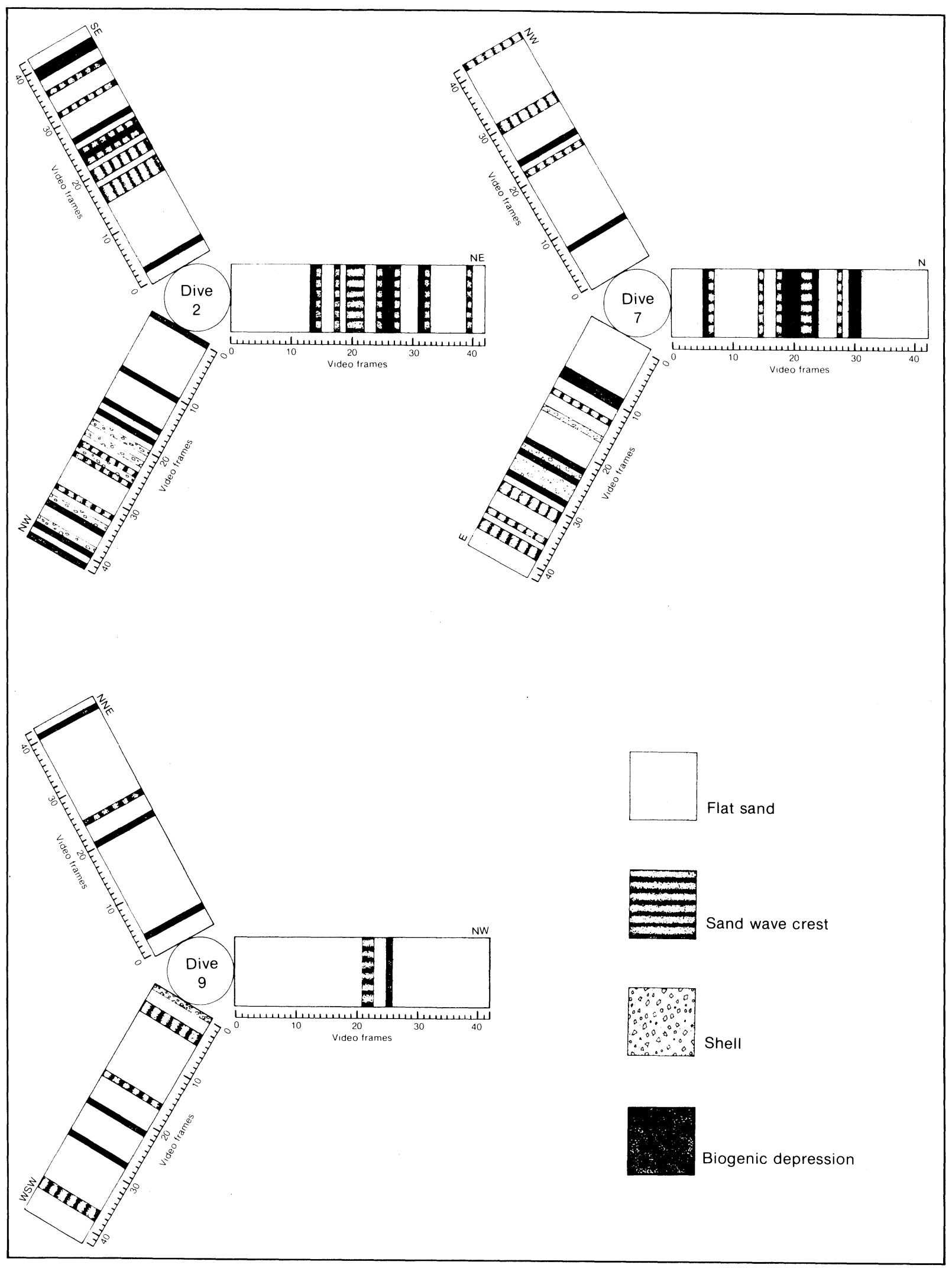

Fig. 4. Substrate variability at the study site. Note variability occurs on the scale of meters. Each dive during the July $1988 \mathrm{cruise}$ consisted of three $50 \mathrm{~m}$ transects radiating from a center point. Direction is noted for each transect. Each video frame is $1.015 \mathrm{~m}^{2}$, and $1.19 \mathrm{~m}$ in length along the axis of the transect. 
TABLE 2. Summary of distribution and abundance (number of individuals) of taxa in each microhabitat type from the July 1988 cruise. $n=$ number of quadrats per substrate type. Chi-square test of homogeneity of distribution $(\alpha=0.05)$ for each species sorted by substrate type.

\begin{tabular}{lrcccc}
\hline \hline & \multicolumn{5}{c}{ Microhabitat type } \\
\cline { 2 - 5 } & $\begin{array}{c}\text { Flat sand } \\
\text { Taxa }\end{array}$ & $\begin{array}{c}\text { Sand wave } \\
\text { crests } \\
(\mathrm{n}=396)\end{array}$ & $\begin{array}{c}\text { Shell } \\
(\mathrm{n}=52)\end{array}$ & $\begin{array}{c}\text { Biogenic } \\
\text { depressions } \\
(\mathrm{n}=48)\end{array}$ & $\begin{array}{c}\text { Chi- } \\
\text { square }\end{array}$ \\
\hline Ocean pout & 11 & 4 & 36 & 4 & sig. \\
Little skate & 4 & 0 & 30 & 4 & sig. \\
Red hake & 9 & 2 & 8 & 2 & ns \\
Silver hake & 40 & 6 & 4 & 0 & sig. \\
Jonah crab & 6 & 1 & 3 & 1 & ns \\
Hermit crab & 2 & 1 & 8 & 0 & sig. \\
Shrimp & 1,040 & 101 & 106 & 116 & sig. \\
Ocean scallop & 3 & 0 & 8 & 1 & sig. \\
Starfish & 1,499 & 178 & 224 & 154 & sig. \\
Tube worm & 47 & 3 & 20 & 3 & ns \\
Hydroid & 83 & 20 & 72 & 31 & sig. \\
\hline
\end{tabular}

TABLE 3. Pearsons product moment correlation coefficients to determine faunal relationships to specific microhabitat types. Data are from the July 1988 cruise. Refer to Table 2 for a summary of numerical abundances. Plus $(+)$ and minus (-) sign alone indicate significant $(\alpha=0.05)$ positive or negative correlation, respectively. NS indicates no significant correlation but sign is included to indicate direction.

\begin{tabular}{|c|c|c|c|c|}
\hline \multirow[b]{2}{*}{ Taxa } & \multicolumn{4}{|c|}{ Microhabitat type } \\
\hline & Flat sand & $\begin{array}{c}\text { Sand wave } \\
\text { crests }\end{array}$ & Shell & $\begin{array}{c}\text { Biogenic } \\
\text { depressions }\end{array}$ \\
\hline Ocean pout & - & NS- & + & NS+ \\
\hline Little skate & - & NS- & + & NS+ \\
\hline Red hake & NS- & NS+ & NS+ & NS+ \\
\hline Silver hake & + & NS+ & - & NS- \\
\hline Jonah crab & NS- & NS+ & NS+ & NS+ \\
\hline Hermit crab & - & NS+ & + & - \\
\hline Shrimp & + & NS- & - & NS+ \\
\hline Ocean scallop & - & NS- & + & NS+ \\
\hline Starfish & + & NS+ & - & NS+ \\
\hline Tube worm & NS+ & NS- & NS+ & NS- \\
\hline Hydroid & - & NS- & + & + \\
\hline
\end{tabular}

were significantly different $(P<0.05)$. Biogenic depressions were not included in this comparison since they occurred in both flat sand and shell areas.

Significant microhabitat preferences were found for 8 of 11 taxa (Table 2). Correlation coefficients (Table 3 ) show the same pattern and indicate negative and positive associations for each taxon-microhabitat combination.

Behavioral observations support the significant statistical patterns. Ocean pout and little skate were positively associated with the shell habitat. Little skate were observed foraging in the shell habitat but not creating typical depressions or camouflaging themselves with surficial sediments. Red hake were also observed to exhibit thigmotactic responses to shell (Fig. 3C) but that association was not statistically significant. Observations during five reconnaissance dives at other sites showed sponges replaced shell as a topographic structure and elicited similar thigmotactic responses of megafauna (Fig. 5).

Silver hake, shrimp and starfish were all positively associated with the flat sand habitat. Silver hake $(n=6)$ were observed to follow flounders and skates for short time periods (ca 5-15 seconds) and prey on shrimp disturbed by their activities (Fig. 6).

Only stalked hydroids were positively associated with the biogenic depression microhabitat. This statistical association may be due to the occurrence of shell material in biogenic depressions. The shell serves as a hard surface for attachment. Biogenic depressions were also used by red hake (Fig. 7A), presumably for station keeping or shelter. Apparently, the little skate created depressions in search of prey and for camouflage (Fig. 7B).

No significant species associations were found for the sand wave crest habitat. Fauna essentially occur at random within this microhabitat. However, silver hake were again observed feeding on drifting demersal zooplankton while oriented into the current on the downcurrent side of the crests.

Most fish species were again in juvenile (prerecruit) size ranges (Table 4 ). Although this represented a relatively small sample which was biased by their orientation to the camera, the individuals measured were representative of the sizes encountered.

\section{November 1988}

Total numbers of all species were low due to a reduced number of transects (Table 5). However, species composition and species-specific behaviours were unique. Species not previously recorded at this site included butterfish, scup and long-finned squid. Butterfish occurred near the bottom over flat sand and shell but never reacted to any bottom feature or contacted the bottom. Scup and long-finned squid both occurred in biogenic depressions. The posture of all squid observed was near horizontal with tentacles pointed down and not in direct contact with the substrate. Scup were observed with their typical nocturnal coloration (vertical bar pattern) and maintaining position in the depressions. Most finfish, as during other observation periods, were in juvenile size ranges.

\section{Seasonal aspects}

The three cruises to the study site, during 2 years and 3 seasons, allowed us to qualitatively estimate the seasonal species composition and microhabitat use by the megafauna (Table 6). Species such as silver hake, little skate and ocean pout occurred during all surveys with some apparent shifts in distribution by microhabitat type. Lobster, scup and long-finned squid were seasonal migrants, occurring during only one of three surveys. Patterns of occurrence of the other species were less clear. For example, red hake were relatively abundant during May and July surveys but only one was observed in November. This may be due to reduced abundance overall or a major shift in distribution. 


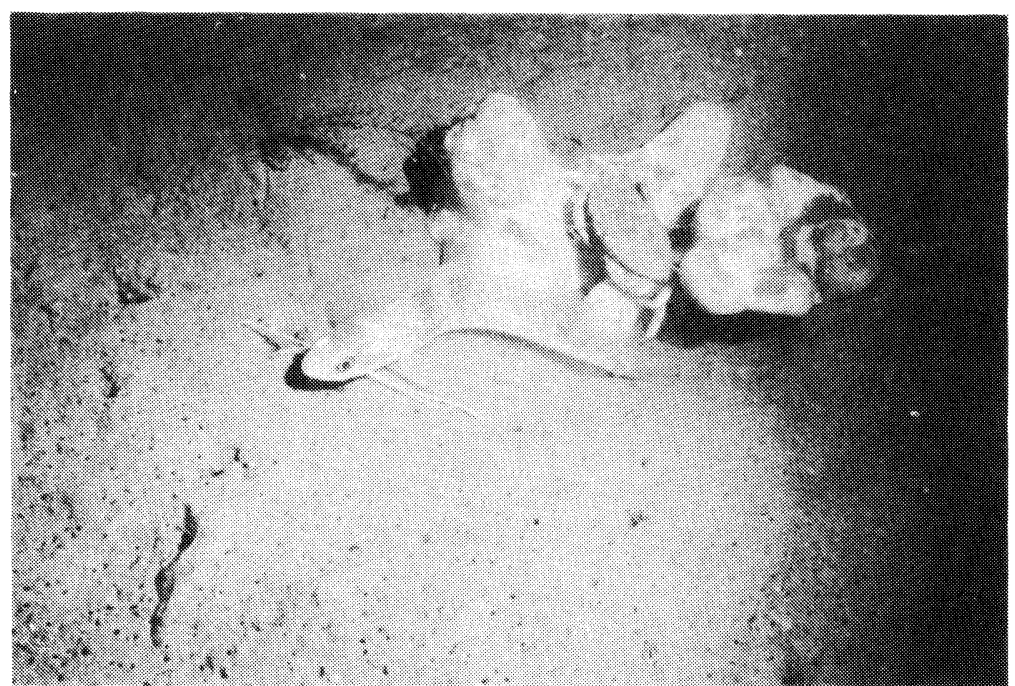

Fig. 5. Thigmotactic responses of red hake and Jonah crab to a sponge (Suberites ficus) on open bottom.

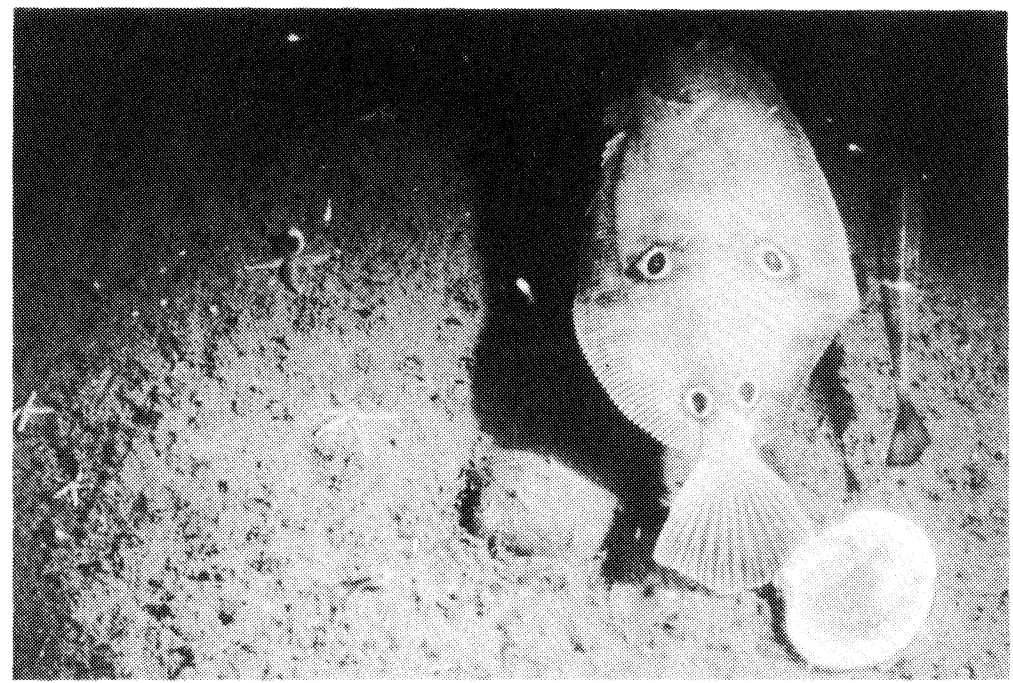

Fig. 6. A silver hake following a four spot flounder in a short time period social foraging association.

Comparisons of more cryptic taxa were not attempted due to variations in the quality of the data between cruises for these forms. For example, while shrimp were observed from the submersible dive in 1987 , they were not easily discerned on the recorded videotype and were not included in any analysis. Also, hydroids and tube worms, were not easily visible during the November dives and again, were not counted.

\section{Discussion}

The results indicate that small-scale distributions of many benthic megafaunal taxa are correlated with specific microhabitat features. These features vary on the scale of meters, contributing to the patchy distribution of megafaunal species. Mesoscale distributions are mediated by the thermal regime (Colton, 1972; Colvocoresses and Musick, 1984; Phoel, 1986) and superimposed on this pattern are the microscale variations we have demonstrated.

While Colvocoresses and Musick (1984) found no mesoscale correlation of fish distribution with sediment type, we found small-scale correlations with 8 of 11 species of megafauna. The species compositions at the present study site did not conform to any specific species group defined in their larger scale study. Component species, identified during each cruise, were a mixture of primarily northern inner shelf and northern mid-shelf species groups (sensu Colvocoresses and Musick, 1984). If each species complex represents groups of functionally similar species, then microhabitat features may be important factors influencing the 

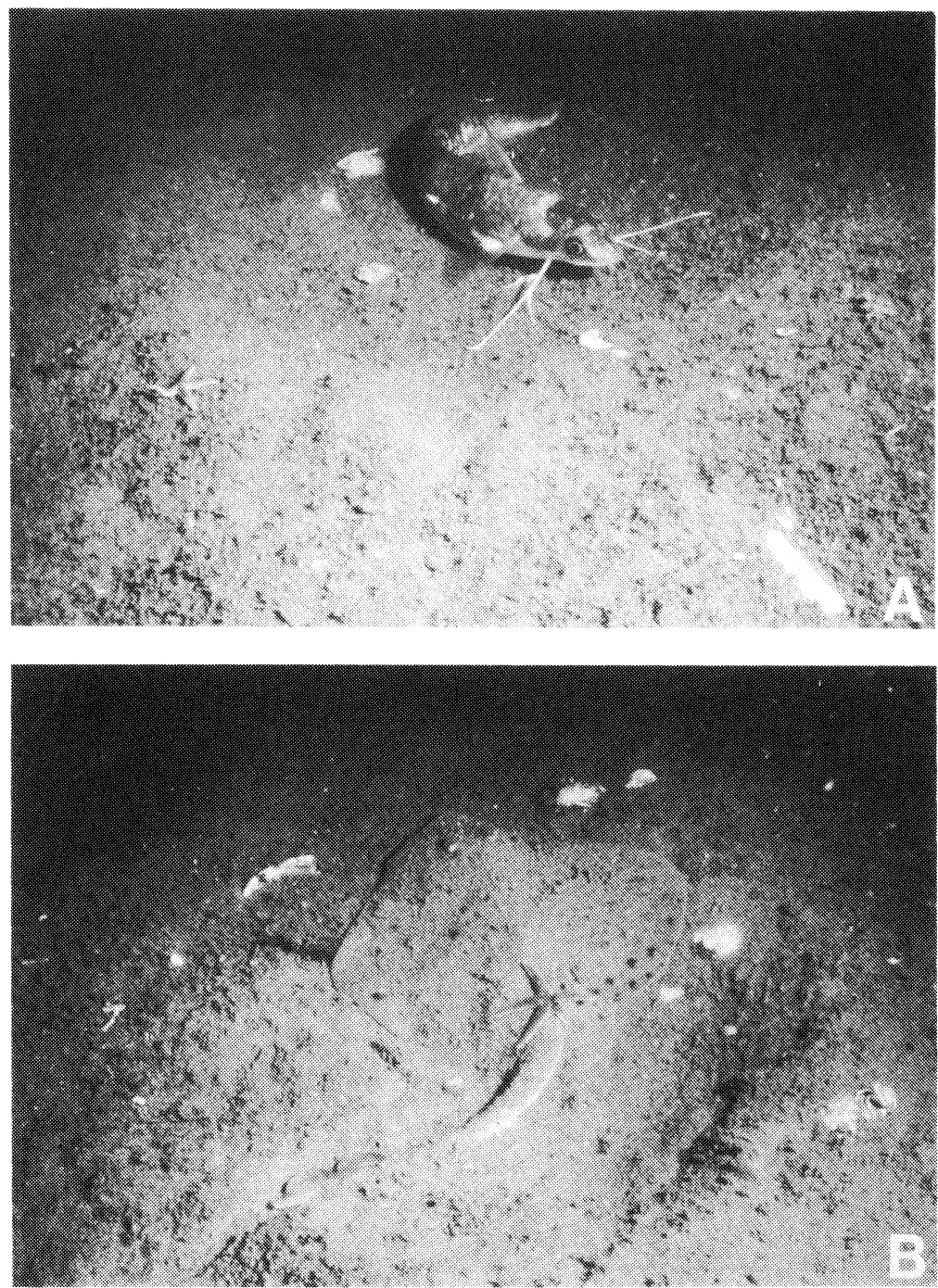

Fig. 7. (A) A red hake in a biogenic depression, formed by this animal or occupied after another individual vacated it. (B) A little skate exiting a depression formed either for camouflage or foraging.

TABLE 4. Sizes (total length in $\mathrm{cm}$ ) of representative taxa estimated from video images. Data are from the July 1988 cruise.

\begin{tabular}{llccr}
\hline \hline \multicolumn{1}{c}{ Taxa } & $\mathrm{N}$ & Mean & Median & \multicolumn{1}{c}{ Range } \\
\hline Ocean pout & 38 & 18.9 & 18.6 & $8.2-44.4$ \\
Little skate & 16 & 34.8 & 35.3 & $26.3-44.4$ \\
Silver hake & 36 & 17.8 & 17.1 & $12.6-27.6$ \\
Red hake & 16 & 21.2 & 20.0 & $15.4-32.8$ \\
\hline
\end{tabular}

small-scale distribution of megafaunal species across the continental shelf.

While significant associations are discernable in these data, it is important to note that many, if not all, mobile taxa may utilize a variety of microhabitats. Indeed the degree of microhabitat heterogeneity may
TABLE 5. Summary of distribution and abundance (number of individuals) by microhabitat type from four ROV transects on a single dive on 15 November 1988.

\begin{tabular}{lcccc}
\hline \hline & \multicolumn{4}{c}{ Microhabitat type } \\
\cline { 2 - 5 } Taxa & Flat sand & $\begin{array}{c}\text { Sand wave } \\
\text { crests }\end{array}$ & Shell & $\begin{array}{c}\text { Biogenic } \\
\text { depressions }\end{array}$ \\
\hline Butterfish & 3 & 0 & 5 & 0 \\
Scup & 2 & 0 & 1 & 4 \\
Ocean pout & 5 & 0 & 2 & 0 \\
Little skate & 3 & 0 & 2 & 6 \\
Red hake & 0 & 0 & 1 & 0 \\
Silver hake & 2 & 0 & 0 & 0 \\
Sea robin & 5 & 0 & 1 & 0 \\
Longhorn sculpin & 1 & 0 & 0 & 0 \\
Flounder & 2 & 0 & 1 & 0 \\
Squid & 0 & 0 & 0 & 3 \\
Starfish & 226 & 0 & 35 & 2
\end{tabular}


TABLE 6. Qualitative list of seasonal (May-July-November) use of microhabitat features at the study site. Bottom water temperatures during May, July and November cruises were interpolated to be $5.7^{\circ}, 7.8^{\circ}$, and $13.2^{\circ} \mathrm{C}$ respectively.

\begin{tabular}{|c|c|c|c|}
\hline \multirow[b]{2}{*}{ Substrate type } & \multicolumn{3}{|c|}{ Seasonal use by taxa } \\
\hline & May & July & November \\
\hline $\begin{array}{l}\text { Flat sand with } \\
\text { amphipod tubes }\end{array}$ & $\begin{array}{l}\text { Silver hake } \\
\text { Little skate } \\
\text { Flounder }\end{array}$ & $\begin{array}{l}\text { Silver hake } \\
\text { Flounder } \\
\text { Shrimp }\end{array}$ & $\begin{array}{l}\text { Silver hake } \\
\text { Sea robin } \\
\text { Ocean pout }\end{array}$ \\
\hline Sand wave crests & Silver hake & Silver hake & - \\
\hline Shell & $\begin{array}{l}\text { Ocean pout } \\
\text { Red hake } \\
\text { Jonah crab } \\
\text { Hermit crab }\end{array}$ & $\begin{array}{l}\text { Ocean pout } \\
\text { Red hake } \\
\text { Jonah crab } \\
\text { Hermit crab } \\
\text { Little skate } \\
\text { Ocean scallop }\end{array}$ & $\begin{array}{l}\text { Ocean pout } \\
\text { Little skate }\end{array}$ \\
\hline $\begin{array}{l}\text { Biogenic } \\
\text { depressions }\end{array}$ & $\begin{array}{l}\text { Lobster } \\
\text { Red hake } \\
\text { Ocean scallop }\end{array}$ & $\begin{array}{l}\text { Red hake } \\
\text { Little skate } \\
\text { Ocean scallop }\end{array}$ & $\begin{array}{l}\text { Little skate } \\
\text { Scup } \\
\text { Ocean scallop } \\
\text { Squid }\end{array}$ \\
\hline
\end{tabular}

influence variability in faunal distributions. For example, in this study ocean pout are positively associated with shell microhabitats, but have been observed foraging on open flat sand, in biogenic depressions and on sand wave crests.

Specific microhabitats, such as shell, may be important as topographic structures rather than because of their specific physical composition. Any three dimensional structure, such as globose sponges, may represent an ecologically equivalent microhabitat. This was clearly demonstrated by the distributional changes in fauna induced by the introduction of artificial reefs of varying composition (e.g., Molles, 1978; Stephan and Lindquist, 1989) and by changes in microhabitat availability in submarine canyons (Cooper et al., 1988).

Individual survivorship partially rests with the ability to capture prey and avoid predators. Juvenile size classes are at greater risk than adults by not yet having obtained a significant refuge from predation by increase in size (e.g. Paine, 1976; Tettelbach, 1986). All of the finfish which utilized shelters (shell and biogenic depressions) were in the juvenile size ranges. In other areas, large shelters such as burrows and boulder crevices were used and maintained by large adult finfish and crustaceans (Able et al., 1982; Grimes et al., 1986; Cooper and Uzmann, 1980). Use of these microhabitats may be dependent on volume, as has been demonstrated for a large size range of lobsters in rock crevices (Stewart, 1972).

Aside from their potential shelter benefit, specific microhabitat features may serve as functional aids to foraging. Silver hake were observed to keep station on the downcurrent side of sand wave crests and ambush drifting demersal zooplankton. The advantage of this strategy appears to be the reduction of energy expended while keeping station. This type of foraging strategy has been observed before on the northeast continental shelf (Auster, 1985) and in kelp bed and coral reef fishes (Hobson and Chess, 1976, 1977). The same energy savings may be had in the occupation of dish depressions by other taxa. Additionally, use of depressions may reduce the distance at which the occupant can be located by potential predators.

A distinction needs to be made between depression makers and users. Observations made during this study and at other sites indicated that while taxa such as skates, hakes and lobsters would excavate depressions, they would also occupy ones that had been previously formed. Other taxa (in this study, squid and scup) utilized abandoned depressions of other species. Therefore, the distribution of certain taxa may be limited by the occurrence of species which form depressions.

Interspecific interactions also contributed to the variable distribution of silver hake across microhabitat types. Silver hake were observed in short time period social foraging associations with skates and flounders. Juvenile silver hake, little skate and flounders, such as the four spot feed primarily on benthic crustaceans (Bigelow and Schroeder, 1953; Langton, 1982; Bowman and Michaels, 1984) such as shrimps and amphipods. Species that swim in contact (or nearly so) with the bottom such as skate and flounder, disturb more area of bottom than silver hake, hence revealing more potential prey.

Seasonal shifts in the mesoscale distribution of species are reflected in the changes in species composition at the study site. Lobster from the outer shelf perform annual migrations inshore during spring and offshore in autumn, following $8^{\circ}$ to $14^{\circ} \mathrm{C}$ isotherms (Cooper and Uzmann, 1980). During these large scale movements, individuals require some form of shelter. Dish depressions are characteristic shelter for lobsters in otherwise featureless habitats (Cooper and Uzmann, 1980). Scup and long-finned squid also make annual inshore-offshore movements (Grosslein and Azarovitz, 1982). Their relationship to specific bottom features have not been previously reported. Scup have been observed nocturnally inshore to actively forage over various sedimentary bottom types (Auster, unpublished data). Squid have been observed near bottom, unrelated to any feature except during spawning and egglaying (Griswold and Prezioso, 1980). Their relationship to biogenic depressions at the present study site may be a response to greater predation risk offshore or as a facultative strategy to increase the probability of prey capture. 
Areas of low topography are favored fishing grounds. The ground gear of otter trawls, as well as scallop drags and clam dredges, have the potential to both disturb and enhance ephemeral microhabitat features such as shell and depressions. For example, while biogenic depressions could easily be destroyed, mortality of clams or scallops (Meyer et al., 1981; Shepard and Auster, 1990) could enhance shell availability. However, direct targeting of bivalve resources which remove the valves from the fishing ground would have the opposite effect. The effects of microhabitat changes induced by fishing activity on groundfish populations have yet to be studied.

Changes in the type, design and deployment strategies of underwater vehicles used in this study are problematic. Each has specific fields-of-view for observers and photographic systems which affect the visibility of certain taxa and change the "quadrat size" of photographs and video images. Additionally, these types of systems are much more weather dependent in their use than other hardware such as trawls. However, small-scale studies using visual methods such as with submersibles, ROVs and camera sleds, coupled with mesoscale trawl sampling, are the only way we will increase our understanding of small-scale processes in low topography marine systems.

\section{Acknowledgements}

Submersible vehicle time and financial support was provided by NOAA's National Undersea Research Center, The University of Connecticut at Avery Point. We gratefully acknowledge the efforts of the crews of the R/V J. W. Powell, R/V Gloria Michele, DSRV Delta and NURC-1 ROV. We thank Dr Paul Fell for identification of the sponge; Mrs Lisa Wahle, Mr Robert DeGoursey, Dr Douglas Lee and two anonymous reviewers for comments which greatly improved the manuscript; and Mrs Susan Stone for artwork.

\section{References}

ABLE, K. W., C. B. GRIMES, R. A. COOPER, and J. R. UZMANN. 1982. Burrow construction and behavior of tilefish, Lopholatilus chamaeleonticeps, Hudson Submarine Canyon. Environ. Biol. Fish., 7: 199-205.

AUSTER, P. J. 1985. Some observations of fish orientation to current direction and effects on predator-prey interactions. NAFO Sci. Coun. Studies, 8: 53-55.

1988. A review of the present state of understanding of marine fish communities. J. Northw. Atl. Fish. Sci., 8: 67-75.

AUSTER, P. J., L. L. STEWART, and H. SPRUNK. 1989. Scientific imaging with ROVs: tools and techniques. Mar. Technol., Soc. J., 23(3): 16-20.

BIGELOW, H. B., and W. C. SCHROEDER. 1953. Fishes of the Gulf of Maine. Fish. Bull. U.S., 53, 577 p.
BOWMAN, R. E., and W. L. MICHAELS. 1984. Food of seventeen species of Northwest Atlantic fish. NOAA Tech. Mem., NMFS-F/NEC-28, $183 \mathrm{p}$.

COLTON, J. B. Jr. 1972. Temperature trends and the distribution of groundfish in continental shelf waters, Nova Scotia to Long Island. Fish. Bull. U.S., 70: 637-657.

COLVOCORESSES, J. A., and J. A. MUSICK. 1984. Species associations and community composition of Middle Atlantic Bight continental shelf demersal fishes. Fish. Bull. U.S., 82: 295-313.

COOPER, R. A., and J. R. UZMANN 1980. Ecology of juvenile and adult Homarus. In: The biology and management of lobsters Vol. II (p. 97-142). J. S. Cobb and B. F. Phillips (eds.). Academic Press, New York, NY.

COOPER, R. A., A. N. SHEPARD, P. VALENTINE, J. R. UZMANN, and A. HULBERT. 1987. Pre and post drilling bench marks and monitoring data of ocean floor fauna, habitats, and contaminant loads on Georges Bank and its submarine Canyons, Symposia Series for Undersea Research 2(2): 17-48. NOAA, Office of Undersea Research, Rockville, MD.

COOPER, R. A., P. VALENTINE, J. R. UZMANN, and R. A. SLATER. 1988. Submarine canyons. In: Georges Bank (p. 52-63). R. H. Backus and D. W. Bourne (eds.). Massachusetts Institute of Technology.

EBELING, A. W., R. J. LARSON, W. S. ALEVIZON, and R. N. BRAY. 1980. Annual variability of reef-fish assemblages in kelp forests off Santa Barbara, California. Fish. Bull. U.S., 78: 361-377.

GASCON, D., and R. A. MILLER. 1981. Colonization by nearshore fish on small artificial reefs in Barkley Sound, British Columbia. Can. J. Zool., 59: 1635-1646.

GRIMES, C. B., K. W. ABLE, and R. S. JONES. 1986. Tilefish, Lopholatilus chamaeleonticeps, habitat, behavior, and community structure in Mid-Atlantic and southern New England waters. Environ. Biol. Fish., 15: 273-292.

GRISWOLD, C. A., and J. PREZIOSO. 1980. In situ observations on reproductive behavior of the long-finned squid Loligo pealei. Fish. Bull. U.S., 78: 945-947.

GROSSLEIN, M. D. and T. R. AZAROVITZ. 1982. Fish distribution. MESA New York Bight Atlas Monograph 15. New York Sea Grant Institute, Albany, N.Y., 182 p.

HACUNDA, J. S. 1981. Trophic relationships among demersal fishes in a coastal area of the Gulf of Maine. Fish. Bull. U.S., 79: 775-788.

HOBSON, E. S. 1974. Feeding relationships of teleostean fishes on coral reefs in Kona, Hawaii. Fish. Bull. U.S., 72: 915-1031.

HOBSON, E. S., and J. R. CHESS. 1976. Trophic interactions among fishes and zooplankters near shore at Santa Catalina Island, California. Fish. Bull. U.S., 74: 567-598.

1977. Trophic relationships among fishes and plankton in the lagoon at Enewetak Atoll, Marshall Islands. Fish. Bull. U.S., 76: 133-153.

LANGTON, R. W. 1982. Diet overlap between Atiantic cod, Gadus morhua, silver hake, Merluccius bilinearis, and fifteen other Northwest Atlantic finfish. Fish. Bull. U.S., 80: 745-759.

LANGTON, R. W., and R. E. BOWMAN. 1980. Food of fifteen Northwest Atlantic gadiform fishes. NOAA Tech. Rep., NMFS-SSRF-740, $23 \mathrm{p}$.

1981. Food of eight Northwest Atlantic pleuronectiform fishes. NOAA Tech. Rep., NMFS SSRF-749, $16 \mathrm{p}$.

MAHON, R., and R. W. SMITH. 1989. Demersal fish assemblages on the Scotian Shelf, Northwest Atlantic: spatial 
distribution and persistence. Can. J. Fish. Aquat. Sci., 46(Suppl. 1): 134-152.

MEYER, T., R. A. COOPER, and K. J. PECCI. 1981. The performance and environmental effects of a hydraulic clam dredge. Mar. Fish. Rev., 43(9): 14-22.

MOLLES, M. C. Jr. 1978. Fish species diversity on model and natural reef patches: experimental insular biogeography. Ecol. Monogr., 48: 289-305.

MOUNTAIN, D. G. MS 1989. TEMPEST, a computer program for estimating temperature on the northeast continental shelf. U.S. Nat. Mar. Fish. Serv., Woods Hole Lab. Ref. Doc. No. 89-02.

OVERHOLTZ, W. J., and A. V. TYLER. 1985. Long-term responses of the demersal fish assemblages of Georges Bank. Fish. Bull. U.S., 83: 507-520.

PAINE, R. T. 1976. Size limited predation: an observational and experimental approach with the Mytilus-Pisaster interaction. Ecology, 57: 858-873.

PARR, A. E. 1933. A geographic-ecological analysis of the seasonal changes in temperature conditions in shallow water along the Atlantic coast of the United States. Bull. Bingham Oceanogr. Coll., IV(3): 1-90.

PHOEL, W. C. 1986. Community structure of demersal fishes on the inshore U.S. Atlantic continental shelf: Cape Ann, Massachusetts to Cape Fear, North Carolina. Ph.D. Dissertation. College of William and Mary.

SALE, P. F. 1972. Influence of corals in the dispersion of the pomacentrid fish, Dascyllus aruanus. Ecology, 53: 741744.

1975. Patterns of use of space in a guild of territorial reef fishes. Mar. Biol., 29: 89-97.

1977. Maintenance of high diversity in coral reef fish communities. Amer. Nat., 11: 337-359.

1978. Coexistence of coral reef fishes - a lottery for living space. Environ. Biol. Fish., 3: 86-102.

1984. The structure of communities of fish on coral reefs and the merit of a hypothesis testing, manipulative approach to ecology. In: Ecological Communities. Conceptual issues and the evidence (p. 478-490). D. R. Strong, Jr. et al. (eds.). Princeton University Press, Princeton, New Jersey.
SEDBERRY, G. R. 1983. Food habits and trophic relationships of a community of fishes on the outer continental shelf. NOAA Tech. Rep., NMFS-SSRF-773, 56 p.

SCOTT, J. S. 1982. Selection of bottom type by groundfishes of the Scotian Shelf. Can. J. Fish. Aquat. Sci., 39: 943-947.

SHEPARD, A. N., and P. J. AUSTER. 1990. Incidental (noncapture) damage to scallops caused by dragging on rock and sand substrates. In: An international compendium of scallop biology and culture. S. Shumway (ed.). World Aquaculture Society and National Shellfisheries Association, Baton Rouge, Louisiana (in press).

SMITH, C. L. 1978. Coral reef fish communities: a compromise view. Environ. Biol. Fish., 3: 109-128.

SMITH, C. L., and J. C. TYLER. 1972. Space resource sharing in a coral reef fish community. Sci. Bull., Nat. Hist. Mus. Los Ang., Cty. 14: 125-170.

1973. Direct observations of resource sharing in coral reef fish. Helgol. Wiss. Meeresunters., 24: 264-275.

1975. Succession and stability in fish communities of dome-shaped patch reefs in the West Indies. Amer. Mus. Novit, 2572: 1-18.

STEPHAN, C. D., and D. G. LINDQUIST. 1989. A comparative analysis of the fish assemblages associated with old and new shipwrecks and fish aggregating devices in Onslow Bay, North Carolina. Bull. Mar. Sci., 44: 698-717.

STEWART, L. L. 1972. The seasonal movements, population dynamics, and ecology of the lobster, Homarus americanus, off Ram Island, Connecticut. Ph.D. Dissertation. The University of Connecticut, Storrs. $112 \mathrm{p}$.

TETTELBACH, S. T. 1986. Dynamics of crustacean predation on the northern bay scallop, Argopecten irradians irradians. Ph.D. Dissertation, The University of Connecticut, Storrs. 229 p.

TYLER, A. V. 1971. Periodic and resident components in communities of Atlantic fishes. J. Fish. Res. Board Can., 29: 997-1003.

UZMANN, J. R., R. A. COOPER, R. B. THEROUX, and R. L. WIGLEY. 1978. Synoptic comparison of three sampling techniques for estimating abundance and distribution of selected megafauna: submersible vs camera sled vs otter trawl. Mar. Fish. Rev., 39(12): 11-19. 
